

\section{\begin{tabular}{l} 
STUDIES IN \\
IMPERIALISM \\
\hline
\end{tabular}}

General editor: Andrew S. Thompson Founding editor: John M. MacKenzie

When the 'Studies in Imperialism' series was founded by Professor John M. MacKenzie more than thirty years ago, emphasis was laid upon the conviction that 'imperialism as a cultural phenomenon had as significant an effect on the dominant as on the subordinate societies'. With well over a hundred titles now published, this remains the prime concern of the series. Cross-disciplinary work has indeed appeared covering the full spectrum of cultural phenomena, as well as examining aspects of gender and sex, frontiers and law, science and the environment, language and literature, migration and patriotic societies, and much else. Moreover, the series has always wished to present comparative work on European and American imperialism, and particularly welcomes the submission of books in these areas. The fascination with imperialism, in all its aspects, shows no sign of abating, and this series will continue to lead the way in encouraging the widest possible range of studies in the field. Studies in Imperialism is fully organic in its development, always seeking to be at the cutting edge, responding to the latest interests of scholars and the needs of this everexpanding area of scholarship.

The souls of white folk

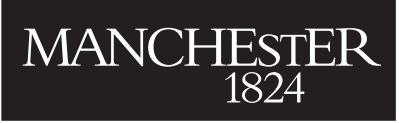

Manchester University Press 
SELECTED TITLES AVAILABLE IN THE SERIES

RACE AND EMPIRE

Eugenics in colonial Kenya

Chloe Campbell

MADNESS AND MARGINALITY

The lives of Kenya's White insane

Will Jackson

SCIENCE, RACE RELATIONS AND RESISTANCE

Britain, 1870-1914

Douglas A. Lorimer

ENDING BRITISH RULE IN AFRICA

Writers in a common cause

Carol Polsgrove

MUSEUMS AND EMPIRE

Natural history, human cultures and colonial identities

John M. MacKenzie 


\title{
The souls of white folk
}

White settlers in Kenya, 1900s-1920s

\author{
Brett L. Shadle
}

MANCHESTER

UNIVERSITY PRESS 
Copyright @ C Brett L. Shadle 2015

The right of Brett L. Shadle to be identified as the author of this work has been asserted by him in accordance with the Copyright, Designs and Patents Act 1988.

Published by MANCHESTER UNIVERSITY PRESS

ALTRINCHAM STREET, MANCHESTER M1 7JA

www.manchesteruniversitypress.co.uk

British Library Cataloguing-in-Publication Data

A catalogue record for this book is available from the British Library

Library of Congress Cataloging-in-Publication Data applied for

ISBN 9781526106810 paperback

This edition first published 2017

The publisher has no responsibility for the persistence or accuracy of URLs for any external or third-party internet websites referred to in this book, and does not guarantee that any content on such websites is, or will remain, accurate or appropriate.

Typeset

by Servis Filmsetting Ltd, Stockport Cheshire 